\title{
RELATIONSHIP OF ENVIRONMENTAL PHYSICAL FACTORS AND LIQUID INTAKE WITH HYDRATION STATUS OF LONTONG HOME INDUSTRY SURABAYA
}

\author{
Ahmad Luqmanul Hakim ${ }^{1}$, Lilis Sulistyorini ${ }^{1}$ \\ ${ }^{1}$ Department of Environmental Health \\ Faculty of Public Health, Airlangga University, Surabaya, Indonesia \\ Address correspondence: Ahmad Luqmanul Hakim \\ E-mail: abinahmadlh@gmail.com
}

\begin{abstract}
A hot working environment can cause health problems for workers, one of them being dehydration. The hydration status of a worker can be influenced by the characteristic of the worker, physical environmental factors, and fluid intake. The objective of this study is to determine the relationship between workers' characteristics, physical environmental factors, and fluid intake with the hydration status of workers. This study was conducted using the cross-sectional design method and used a simple random sampling technique to select 17 respondents and 17 home industries originally derived from 20 respondents and 20 home industries. The research location was on Jalan Banyu Urip Lor X Surabaya. Data were analyzed using cross-tabulation and fisher's exact test with a confidence level of $95 \%$. The data were collected through interviews, measurements, questionnaires, and verification. The results showed that there was a significant relationship between physical environmental factors, which included temperature $(\mathrm{p}=0.002)$, humidity $(\mathrm{p}=0.029)$, and fluid intake $(\mathrm{p}=0.029)$, with the hydration status of workers. In general, it can be concluded that physical environmental factors and fluid intake are relevant towards the hydration status of workers. Therefore, it is recommended that the workers improve air circulation in the room by adding natural ventilation, an exhaust fan in the kitchen, and are advised to consume enough mineral water while working.
\end{abstract}

Keywords: temperature, humidity, fluid intake, hydration status

\begin{abstract}
ABSTRAK
Lingkungan kerja panas dapat menyebabkan beberapa gangguan kesehatan bagi pekerja, salah satunya dehidrasi. Status hidrasi pekerja dapat dipengaruhi oleh karakteristik pekerja, faktor fisik lingkungan dan asupan cairan. Tujuan dari penelitian ini untuk mengetahui hubungan karakteristik pekerja, faktor fisik lingkungan dan asupan cairan dengan status hidrasi pekerja. Penelitian ini menggunakan rancangan penelitian potong-lintang dengan jumlah sampel 17 responden dan 17 industri rumah tangga yang diambil menggunakan sistem pengambilan acak sederhana dari 20 responden dan 20 industri rumah tangga. Lokasi penelitian di Jalan Banyu Urip Lor X Surabaya. Data dianalisa menggunakan tabulasi silang dan uji fisher's exact dengan selang kepercayaan sebesar 95\%. Data dikumpulakan dengan cara wawancara, pengukuran, kuisioner dan pemeriksaan. Hasil penelitian menunjukkan ada hubungan yang signifikan antara faktor fisik lingkungan yang meliputi suhu (p $=0,002)$ dan kelembapan $(p=0,029)$ serta asupan cairan $(p=0,029)$ dengan status hidrasi pekerja. Secara umum dapat disimpulkan bahwa faktor fisik lingkungan dan asupan cairan berhubungan dengan status hidrasi pekerja. Oleh karena itu, pekerja disarankan untuk mengatur sirkulasi udara dalam ruangan dengan penambahan ventilasi alami dan sungkup udara di dalam dapur, serta mencukupi konsumsi air minum mineral saat bekerja.
\end{abstract}

Kata Kunci: suhu, kelembapan, asupan cairan, status hidrasi

\section{INTRODUCTION}

Year to year, economic growth in Indonesia continues to increase. Data from Statistics Indonesia (BPS) show that in 2016 it reached $5.03 \%$, increasing to $5.07 \%$ in 2017 and $5.17 \%$ in 2018. One contributor of this economic growth is the industrial sector. Surabaya is one of Indonesia's big cities, leading the country's industrial, trade, and service sectors. Economic growth in Surabaya is not only generated by large industries but also small household industries (Ningsih, 2018).

The relationship between industry and workers are inseverable on the grounds 
that work productivity is the goal of each industry. Healthy workers can increase work productivity and reduce absence due to illness. A balance in workload and additional burden free work environment with a worker's unobstructed capacity will guarantee better health conditions and increase work productivity (Suma'mur, 2009). Physical factors of the daily workplace environment contain many direct and indirect dangers to workers (Septiana dan Widowati, 2017). Based on the number of accidents published by the International Labor Organization (ILO) in 2016, 6,300 workers died per day or more than 2.3 people due to work-related accidents and diseases. The estimated loss from workrelated accidents and diseases that year was US \$ 2.8 trillion (ILO, 2016).

Surabaya has a small and household industrial sector, one of which is in the culinary field manufacturing rice cakes (lontong). This rice cake home industry located on Jalan Banyu Urip Lor X Surabaya is the main source of livelihood for most of the surrounding residents. Besides being able to improve the economy of each of its residents, the rice cake business also comes with some negative impacts. Home industries are generally managed individually and thus ignore work regulations related to health and environment (Ningsih, 2018). Based on the Regulation of the Indonesian Minister of Health Number 70 of 2016 concerning Standards and Health Requirements for the Industrial Work Environment, each industry is required to meet the health standards of the work environment. Its regulatory purpose is to ensure that there are no adverse impacts on workers regarding health.

The lontong cooking activity is centered on Jalan Banyu Urip Lor X, Kupang Krajan Village, Sawahan District, Surabaya City. The process of cooking lontong, also known as rice cake in Indonesian, based on the results of preliminary studies, impacts workers health negatively if not managed properly. The impact that arises from this manufacturing process is dehydration of the workers. This is due to the long periods of time making and cooking rice cakes, which is carried out for 8-10 hours daily exposing workers to long spans working in the heat. Rice cake cooking is carried out in houses located in densely populated settlements. This can cause dehydration and other health risks if not accompanied by adequate fluid intake. This rice cake home industry, in a day, can produce from 700 to 2000 packs. As a result of this production rate, workers making rice cakes are more exposed to heat generated by furnaces. The number of stoves used in each house also varies per business. Small scale production requires 3 cooking stoves every day, while for medium to large scales use 4 to 5 every day.

The initial temperatures of the working environment per house were collected, measuring at house $1\left(33.0^{\circ} \mathrm{C}\right)$, house $2\left(32.5^{\circ} \mathrm{C}\right)$, and house $3\left(33.6^{\circ} \mathrm{C}\right)$. According to Moeljosoedarmo (2008), a hot work environment that exceeds the threshold value can cause health problems, one of which is dehydration. Dehydration is defined as the loss of excess fluid, one contributing cause being excessive sweating (Pranata, 2013). In addition to hot environmental temperatures, dehydration can occur due to a lack of fluid intake into the body (Huda, 2016). According to Grandjean (2009), there is a minimum fluid intake recommendation where per day, male workers working in hot environments are advised to consume a minimum of 3.7 liters of fluids, and women are recommended 2.7 liters.

Heat in a work environment has an influence on environmental physical factors such as temperature and humidity. A person's hydration status are influenced by the characteristics of the worker, namely age, sex, and duration of work. Based on these factors, this study was conducted to analyze the relationship between worker characteristics, environmental physical factors, and worker fluid intake through hydration status. 


\section{METHODS}

This study is classified as an analytic observational study. Due to the research time line, a cross-sectional study design was used because the data collection on the independent and dependent variable was carried out at the same time. Data collection took place from March 2 to March 12, 2019. This study was conducted on Jalan Banyu Urip Lor X, Kupang Krajan Village, Sawahan District, Surabaya City. The population of this study were 20 people, who worked as lontong makers, and 20 houses which were being used for lontong-making activities. The sample size in this study was determined by the calculation of the Lameshow formula, resulting in the choice of analyzing 17 respondents and 17 houses. The sampling was done using the simple random sampling technique. The requirements for prospective respondents were those who (1) were not sick, (2) were not taking drugs before and during the study, and (3) were not fasting. All the respondents included in this study have met the requirements of the exclusion criteria.

The independent variables were worker characteristics (age, sex, and length of work), environmental physical factors (temperature and humidity), and daily fluid intake. The dependent variable was the hydration status of the workers. Data were collected using interviews for worker characteristics, using a thermohygrometer for environmental physical factors such as temperature and humidity, questionnaires for workers' fluid intake and examinations using urine color indicators to determine their hydration status. The data were analyzed first using univariate and bivariate method, followed by the fisher's exact test and cross-tabulation with a confidence interval of $95 \%(\alpha=0.05)$. This research has received approval from the ethics committee of the Faculty of Public Health, Universitas Airlangga and passed the ethical review No. 60/EA/KEPK/2019.

\section{RESULTS}

Results of the study on rice cake home industry on Jalan Banyu Urip Lor X Surabaya, were presented as follows.

\section{Worker Characteristics, Environmental Physical Factors, and Fluid Intake}

Based on the results in Table 1, the variable for characteristics of workers in the rice cake home industry were found that 10 workers $(58.8 \%)$ were less than 40 years old. Regarding sex variable, 12 workers $(70.6 \%)$ were women. Furthermore, 15 workers $(88.2 \%)$ work for more than the required minimum period of 8 hours a day.

Table 1. Distribution of Characteristics of the Rice Cake Home Industry on Jalan Banyu Urip Lor X Surabaya in 2019

\begin{tabular}{lcc}
\hline \multicolumn{1}{c}{ Variable } & n & \% \\
\hline Age & & \\
\hline 18-40 years & 10 & 58.8 \\
\hline 40-60 years & 7 & 41.2 \\
\hline Gender & & \\
\hline Man & 5 & 29.4 \\
\hline Women & 12 & 70.6 \\
\hline $\begin{array}{l}\text { Length } \\
\text { working }\end{array}$ & & \\
\hline 5-8 hours & 2 & 11.8 \\
\hline$>8-10$ hours & 15 & 88.2 \\
\hline
\end{tabular}

The results of the study shown in Table 2 on the variables of environmental physical factors include air temperature and humidity. Most temperatures of the industry have met the assessment indicators. The Regulation of the Indonesian Ministry of Health Number 1405 of 2002 concerning Health Requirements for Office and Industrial Work Environment states that the standard for air temperature in a work environment is between $18^{\circ} \mathrm{C}-30^{\circ} \mathrm{C}$. Conjointly, it also states that the standard of humidity in a work environment should be $65 \%-95 \%$. 
Table 2. Distribution of Physical Environmental Factors in Rice Cake Home Industry on Jalan Banyu Urip Lor X Surabaya in 2019

\begin{tabular}{lrc}
\hline \multicolumn{1}{c}{ Variable } & n & \% \\
\hline Temperature & & \\
\hline Fulfill & 10 & 58.8 \\
\hline Does not meet the & 7 & 41.2 \\
\hline Moisture & & \\
\hline Fulfill & 12 & 70.6 \\
\hline Does not meet the & 5 & 29.4 \\
\hline
\end{tabular}

Table 3 shows that the fluids consumed by a majority of the workers were less than the stipulated requirements. The minimum recommended fluid intake standards for male and female workers are different. In a hot work environment, male workers consume a minimum of 3.7 liters per day and women 2.7 liters per day (Grandjean, 2009).

Table 3. Distribution of Fluid Intake of Rice Cake Home Industry on Jalan Banyu Urip Lor X Surabaya in 2019

\begin{tabular}{lrc}
\hline \multicolumn{1}{c}{ Variable } & n & \% \\
\hline Fluid intake & & \\
\hline Less & 13 & 76.5 \\
\hline Enough & 4 & 23.5 \\
\hline
\end{tabular}

Table 4. Distribution of Hydration Status for Rice Cake Home Industry on Jalan Banyu Urip Lor X Surabaya in 2019

\begin{tabular}{llc}
\hline \multicolumn{1}{c}{ Variable } & n & \% \\
\hline Urine Color & & \\
\hline Not Dehydrated & 2 & 11.8 \\
\hline Mild Dehydration & 6 & 35.3 \\
\hline $\begin{array}{l}\text { Moderate } \\
\text { Dehydration }\end{array}$ & 9 & 52.9 \\
\hline $\begin{array}{l}\text { Severe } \\
\text { Dehydration }\end{array}$ & 0 & 0.0 \\
\hline
\end{tabular}

Based on Table 4, the results of the urine color examination using a urine color table (Armstrong et al., 1994) found that only 2 workers (11.8\%) were not dehydrated. Meanwhile, 6 workers (35.3\%) were mildly dehydrated, and as many as 9 workers $(52.9 \%)$ were moderately dehydrated.

The results of cross-tabulation between age and hydration status of workers aged 18-40 years shows that 2 workers $(22.2 \%)$ were mildly hydrated, 5 workers $(55.9 \%)$ were moderately hydrated, and 2 workers $(22.2 \%)$ were not dehydrated (see Table 5). Meanwhile, in the age group of 40-60 years, there were $4(50.0 \%)$ mildly hydrated workers and $4(50.0 \%)$ moderately hydrated workers. The fisher's exact test was carried out between the age of the worker and the worker's hydration status. A $\mathrm{p}$-value of 1.000 is greater than 0.05 , which means that there is no significant relationship between age and the worker's hydration status.

The results of univariate analysis between the hydration status of workers and sex are as follows. For women, 4 workers $(33.3 \%)$ were mildly hydrated, 7 workers $(58.3 \%)$ were moderately hydrated, and 1 worker $(8.3 \%)$ was not dehydrated. On the other hand, for men, 2 workers $(40.0 \%)$ were mildly and moderately hydrated, and only 1 worker $(20.0 \%)$ was not dehydrated (see Table 5). The results of the fisher's exact test that has been carried out between the sex of the worker and the worker's hydration status, it has a p-value of 0.620 which is greater than 0.05 . Therefore, there is no significant relationship between sex and the worker's hydration status.

Based on Table 5, the results of the cross-tabulation between the number of daily working hours and the workers' hydration are as follows. One worker (50.0\%) working 5-8 hours a day was moderately hydrated, while others were fully hydrated. Concurrently, for workers working for more than 8-10 hours a day, 6 workers $(40.0 \%)$ were mildly hydrated, and 8 workers $(53 \%)$ were moderately hydrated. However, 1 worker (6.7\%) was not dehydrated. A fisher's exact test that had been carried out between the number of 
daily working hours and the worker's hydration, with a $(\mathrm{p}=1.000)$ greater than
0.05 , shows that there is no significant relationship between the two variables.

Table 5. Cross-Tabulation of Worker Hydration Status according to the Characteristics of Rice Cake Home Industry on Jalan Banyu Urip Lor X Surabaya in 2019

\begin{tabular}{|c|c|c|c|c|c|c|c|c|c|}
\hline \multirow{3}{*}{ Variable } & \multicolumn{6}{|c|}{ Hydration Status } & & & \multirow{3}{*}{$p$} \\
\hline & \multicolumn{2}{|c|}{ No Dehydration } & \multicolumn{2}{|c|}{$\begin{array}{c}\text { Mild } \\
\text { Dehydration }\end{array}$} & \multicolumn{2}{|c|}{$\begin{array}{c}\text { Moderate } \\
\text { Dehydration }\end{array}$} & \multicolumn{2}{|c|}{ Total } & \\
\hline & $\mathbf{n}$ & $\%$ & n & $\%$ & $\mathbf{n}$ & $\%$ & $\mathrm{n}$ & $\%$ & \\
\hline \multicolumn{10}{|l|}{ Age (years) } \\
\hline $18-40$ & 2 & 22.2 & 2 & 22.2 & 5 & 55.6 & 9 & 100.0 & \multirow{2}{*}{1.000} \\
\hline$>40-60$ & 0 & 0.0 & 4 & 50.0 & 4 & 50.0 & 8 & 100.0 & \\
\hline \multicolumn{10}{|l|}{ Gender } \\
\hline Man & 1 & 20.0 & 2 & 40.0 & 2 & 40.0 & 5 & 100.0 & \multirow{2}{*}{0.620} \\
\hline Women & 1 & 8.3 & 4 & 33.3 & 7 & 58.3 & 12 & 100.0 & \\
\hline \multicolumn{10}{|c|}{ Length of working } \\
\hline 5-8 hours & 1 & 50.0 & 0 & 0.0 & 1 & 50.0 & 2 & 100.0 & \multirow[b]{2}{*}{1.000} \\
\hline $\begin{array}{l}>8-10 \\
\text { hours }\end{array}$ & 1 & 6,7 & 6 & 40.0 & 8 & 53.3 & 15 & 100.0 & \\
\hline
\end{tabular}

Table 6. Cross-Tabulation of Worker Hydration Status according to Physical Environmental Factors Rice Cake Home Industry on Jalan Banyu Urip Lor X Surabaya Year 201

\begin{tabular}{|c|c|c|c|c|c|c|c|c|c|}
\hline \multirow{3}{*}{ Variable } & \multicolumn{6}{|c|}{ Hydration Status } & \multirow{2}{*}{\multicolumn{2}{|c|}{ Total }} & \multirow{3}{*}{$\begin{array}{c}p \\
\mathbf{n} \\
\end{array}$} \\
\hline & \multicolumn{2}{|c|}{ No Dehydration } & \multicolumn{2}{|c|}{$\begin{array}{c}\text { Mild } \\
\text { Dehydration }\end{array}$} & \multicolumn{2}{|c|}{$\begin{array}{c}\text { Moderate } \\
\text { Dehydration }\end{array}$} & & & \\
\hline & $\mathrm{n}$ & $\%$ & n & & $\mathbf{n}$ & $\%$ & $\mathbf{n}$ & & \\
\hline \multicolumn{10}{|c|}{ Temperature } \\
\hline Fulfill & 2 & 20.0 & 6 & 60.0 & 2 & 20.0 & 10 & 100 & \multirow[b]{2}{*}{0.002} \\
\hline $\begin{array}{l}\text { Does not } \\
\text { meet the }\end{array}$ & 0 & 0.0 & 0 & 0.0 & 7 & 100 & 7 & 100 & \\
\hline \multicolumn{10}{|l|}{ Moisture } \\
\hline Fulfill & 2 & 16.7 & 6 & 50.0 & 4 & 33.3 & 12 & 100 & \multirow[b]{2}{*}{0.029} \\
\hline $\begin{array}{l}\text { Does not } \\
\text { meet the }\end{array}$ & 0 & 0.0 & 0 & 0.0 & 5 & 100 & 5 & 100 & \\
\hline
\end{tabular}

The univariate analysis shows at temperatures which did not meet the assessment indicators, seven workers $(100 \%)$ were moderately hydrated (see Table 6). On the other hand, at temperatures which met the assessment indicators, there are $6(60.0 \%)$ mildly hydrated workers, 2 (20\%) moderately hydrated workers, and another $2(20.0 \%)$ workers who were not dehydrated. The fisher's exact test between the air temperature of the work environment and the hydration status of the workers shows that there was a significant relationship between the two variables $(\mathrm{p}<$ 0.002).
The results of cross-tabulation between the humidity of the work environment and the worker's hydration status shows that at humidity that met the standard, there were 5 workers $(100 \%)$ who were moderately hydrated. Whereas, in humid conditions that met the assessment indicators, there were $6(50.0 \%)$ mildly hydrated workers, 4 (33.3\%) moderately hydrated workers, and $2(16.7 \%)$ hydrated workers. The fisher's exact test between the humidity of the work environment and the hydration status of the workers shows a significant relationship between the two variables $(\mathrm{p}=0.029)$. 
Table 7. Cross-tabulation of Worker Hydration Status according to Workers' Fluid Intake of Rice Cake Home Industry on Jalan Banyu Urip Lor X Surabaya in 2019

\begin{tabular}{|c|c|c|c|c|c|c|c|c|c|}
\hline \multirow{3}{*}{$\begin{array}{l}\text { Fluid } \\
\text { intake }\end{array}$} & \multicolumn{6}{|c|}{ Hydration Status } & \multirow{2}{*}{\multicolumn{2}{|c|}{ Total }} & \multirow[b]{2}{*}{$p$} \\
\hline & \multicolumn{2}{|c|}{ No Dehydration } & \multicolumn{2}{|c|}{$\begin{array}{c}\text { Mild } \\
\text { Dehydration }\end{array}$} & \multicolumn{2}{|c|}{$\begin{array}{c}\text { Moderate } \\
\text { Dehydration }\end{array}$} & & & \\
\hline & $\mathbf{n}$ & $\%$ & $\mathbf{n}$ & $\%$ & $\mathbf{n}$ & $\%$ & $\mathbf{n}$ & $\%$ & \multirow{4}{*}{0.029} \\
\hline Less & 1 & 7.7 & 3 & 23.1 & 9 & 69.2 & 13 & 100 & \\
\hline Enough & 1 & 25.0 & 3 & 75.0 & 0 & 0.0 & 4 & 100 & \\
\hline Total & 2 & 11.8 & 6 & 35.3 & 9 & 52.9 & 17 & 100 & \\
\hline
\end{tabular}

The results of cross tabulation between workers' fluid intake and hydration status showed that when insufficiently consuming fluid, 3 workers $(23.1 \%)$ were mildly hydrated, $9(69.2 \%)$ were moderately hydrated, and $1(7.7 \%)$ was not dehydrated (see Table 7). Meanwhile, those who consumed a sufficient amount of fluid only show 3 workers $(75 \%)$ experiencing mild dehydration. The results of the fisher's exact test between workers' fluid intake and hydration status showed a significant relationship $(\mathrm{p}=0.029)$.

\section{DISCUSSION}

The rice cake manufacturing on Jalan Banyu Urip Lor X Surabaya uses rice as the raw materials as well as banana leaves and sticks to wrap the rice. After the rice cake is ready to be cooked, it is put in a pan and cooked for 8-10 hours. Each home industry is capable of producing 700 to 2,000 lontong every day. Lontong makers are at risk of exposure to heat from its prolonged cooking time. When cooking activities are long enough, it can trigger an increase in temperature and humidity in the work environment. Taking that into consideration, when paired with inadequate fluid intake, it can cause disruption of hydration status causing dehydration in workers (Hew-Butler et al., 2018).

According to Almatsier (2009), a workers' hydration status is determined by the balance between fluid intake that enters the body and that that leaves the body. Therefore, excessive amounts of water in the body or a lack thereof does not cause dehydration. The intake of fluids comes from foods, drinks, and water obtained from metabolism. Fluid that leaves the body are secreted through urination, water in the feces, and sweating from skin. Based on the research results, more than $50 \%$ of workers are moderately hydrated, however, on the other hand another $50 \%$ of workers have less fluid consumption.

\section{The Relationship between Worker Characteristics and Hydration Status}

The characteristic variables in this study include the age, sex, and duration of work a day for workers. The fisher's exact test between the age of the worker and the worker's hydration status showed no statistical relationship between the age of the worker and the worker's hydration status $(\mathrm{p}(1.000)>0.05)$.

This research is not in line with the research conducted by Rasyid (2018) who states that a person's hydration status could be influenced by physical environmental factors and internal factors of workers including age, gender, body mass index, fluid consumption, workload, and work shift. Nawawinetu (2010) argues that age can affect a person's ability to tolerate heat in its work environment. At less than 40 years of age, the condition of a person's body is quick to respond to the heat around it, while people aged more than 40 years can handle heat to decrease (Nawawinetu, 2010).

The surveys conducted show that more workers were less than 40 years old, thus their bodies were still in good condition. As a result, their ability to 
tolerate heat exposure in a working environment was still high. This result is in line with a research conducted by Ningsih (2018) stating that the age of workers and the dehydration status of workers in the fish smoking home industry was not statistically related. Age is not the main factor affecting hydration, but age is a factor that affects how a body regulates temperature when a person is in a hot environment.

The results of fisher's exact test between the sex of the worker and the hydration status obtained show no statistical relationship between the two variables ( $p$ $(0.620)>0.05)$. The results of this study are not in line with the theory described by Tarwaka (2011), who states female workers in hot environments were more vulnerable than their male counterparts. Tarwaka explained that because a woman's body has tissue with higher conductivity to heat exposure, female workers give out more peripheral reactions in the form of sweat when in a hot work environment. Furthermore, the results if this study are in line with research conducted by Ningsih (2018)which finds no relationship between the sex of the worker and their hydration status. Sex is not an important factor in influencing the hydration status of workers, as is the same with age.

The results of the fisher's exact test show no statistical relationship between the durration of work and the worker's hydration status $(\mathrm{p}(1.000)>0.05)$. This research is thus not in line with a research conducted by Effendi (2016) which states that there is a relationship between total daily working hours and the level of dehydration in home industry workers of STMJ Surabaya. Under the opposite condition, with less than 8 hours a day as many as 5 workers $(62.5 \%)$ did not experience dehydration.

\section{The Relationship between Physical Environmental Factors and Worker Hydration Status}

The variables of physical environmental factors studied in the rice cake home industry on Jalan Banyu Urip Lor X Surabaya include the temperature and humidity of the work environment during the production process. Based on the results of the fisher's exact test, there was a significant relationship between temperature and hydration status. A hot work environment is characterized by everpresent high temperatures affecting thermal comfort while doing activities at work (Sayuti dan Susanto, 2017)..

This research is in line with a research conducted by Ningsih (2018) on the fish smoking home industry, where there was a significant relationship between the temperature of the workplace environment and the level of dehydration. At places which temperatures met assessment indicators, 5 workers were dehydrated. On the other hand, 12 workers experienced severe dehydration when working in temperatures which did not meet the assessment indicators. The contingency coefficient value of Ningsih's research is 0.603 which means that the correlation between temperature and dehydration level of fish smoking workers is strong.

Another research conducted by Andayani (2013) shows that a high working environment temperature of more than $30^{\circ} \mathrm{C}$ could cause dehydration. As many as $37 \%$ of workers were classified as mildly hydrated, $15 \%$ as moderately hydrated, and $19.2 \%$ as over dehydrated.

When a worker is carrying out activities in a workplace that exceeds the threshold value for air temperature, they will experience heat stress. The effects of heat stress received by workers can cause several subjective complaints including hot flashes, profuse sweating, constant thirst, and a loss of appetite, all caused by the discharge fluids through sweat (Suma'mur, 2009).

According to Moeljosoedarmo (2008), lowering the temperature of a hot environment is one of the recommended ways to specifically control the area. When the air temperature exceeds the heat exposure threshold value, the workforce 
will feel a real increase in heat from the work environment. Lower air temperatures can help reduce the additional heat received and therefore increase heat loss. The air temperature in a room can be lowered by installing ventilation, which introduces cooler air from other places (outside the kitchen) into the hot working environment causing cold air to mix with hot air. Besides, it can be done installing an exhaust fan to circulate air outside the room.

The next variable is the humidity in a work environment. Based on the results of the statistical tests, there was a relationship between the humidity in the work environment and the hydration status of the rice cake making workers on Jalan Banyu Urip Lor $X$ Surabaya. Similar to environmental temperature, environmental humidity is one of the factors that affect thermal comfort in a work environment (Ashadi dan Anisa, 2017). Humidity in an environment can be caused by several factors including personal factors and house building factors (Sukowiyono dan Susanti, 2018).

This research is in line with Sari's (2014) research conducted towards boiler workers at PT. Albasia Sejahtera Mandiri Semarang Regency. It concluded that there was a relationship between the hot working environment and the dehydration levels of workers $(\mathrm{p}(0.023)<0.05)$. In this study, humidity is one of the components observed in the work climate.

Another study conducted by Ningsih (2018) on the fish smoking home industry workers found that there was a significant relationship between humidity in the work environment and the level of dehydration. The results showed that 6 workers were not dehydrated in conditions where the humidity did not meet the assessment indicator, between 65\%-95\%, while there were 11 workers who were dehydrated at a humidity of less than $65 \%$. The correlation coefficient value is 0.623 , meaning that the humidity of the air and the level of dehydration of workers are linked.
Controlling humidity in the work environment can be done by reducing the humidity in the air. The lower the humidity in an environment, the lower the heat pressure in the environment. If the air temperature and humidity levels are low, evaporation will be accelerated by cooling, making the room feel more comfortable during activity (Moeljosoedarmo, 2008).

\section{The Relationship between Fluid Intake and Worker Hydration Status}

The results of fisher's exact test between the fluid intake and the hydration status of the rice cake home industry workers shows a significant relationship. Working in a hot work environment, if not followed by adjustment, will have a negative impact on the worker's body. Workers in hot work environments are encouraged to consume an average of 2.7 liters of drinking water a day for female and 3.7 liters a day for males (Grandjean, 2009). The study shows that workers who consume enough fluids had good hydration status. Conversely, workers who consume less fluids were in the moderate hydration classification.

According to Moeljosoedarmo (2008), workers who are working in a hot work environment are required to meet the intake of fluids lost through sweat. Workers are required to consume at least 1 glass of drinking water every $15-20$ minutes or 2030 minutes. The water is recommended to be relatively cold, about $\pm 10^{\circ} \mathrm{C}-15^{\circ} \mathrm{C}$ and placed close in a clos distance to the work place. In addition, if workers have not acclimatized the conditions they are advised to drink fluids that contains $0.2 \%$ of salt.

The home industry workers making lontong admitted that they only drank when they were thirsty. According to Asmadi (2008), the habit of drinking only when thirsty is bad. When a person feels thirsty, the body has already lost as much as $1-2 \%$ of the body weight in fluids. The body's response to thirst is controlled by the central nervous system. The feeling of thirst in a person appears a few minutes after the main 
organs in the body are dehydrated. This is because most people do not know that drinking water before the onset of thirst is better than after. Therefore, drinking water only when feeling thirsty should be avoided in order for the body to remain in good condition and is to carry out activities optimally.

The results of this research are also in line with research conducted by Sari (2017) to employees of PT. Candi Mekar Pemalang in the weaving section. It concluded that there was a significant relationship between workers water consumption and dehydration with a pvalue of 0.001 . Moreover, in the research conducted by Andayani (2013), there was a significant relationship between worker fluid intake and dehydration levels ( $\mathrm{p}$ $(0.006)<0.05)$.

This study did not specifically conduct an in-depth analysis of the relationship between workers' fluid intake and hydration status; however, a study conducted by Rohadi (2018) shows that workers' fluid intake was negatively related to the hydration status of workers in the Meat Powder Extract (EMP) division of PT. Ajinomoto Indonesia Mojokerto Factory ( $\mathrm{r}$ $=-0.398 ; \mathrm{p}=0.024)$. This provides supporting argument that the lower the workers fluid intake, the higher the risk of experiencing dehydration. It can be concluded that this study is in line with previous studies where there was a significant relationship between workers' fluid intake and their hydration status.

\section{CONCLUSION}

Based on the results of this study, it can be concluded that there is no relationship between worker characteristics such as age, sex, and length of work with hydration status. There is, however, a significant relationship between environmental physical factors such as temperature and humidity of the work environment with the hydration status of workers. Furthermore, fluid intake does have a significant relationship with the hydration status of workers.

The study recommends to respondents to regulate air circulation in the lontong home indutry, both naturally and artificially, through installation of hot air exhaust or exhaust fans in the rooms to allow cooler and less smoky air. It is also important for home industry workers to meet the recommended daily fluid intake. Additionally, this study recognizes the need for counseling about the importance of drinking water at work and the dangers of dehydration for home industry workers who produce lontong on Jalan Banyu Urip Lor X Surabaya.

\section{REFERENCE}

Almatsier, S., 2009. Prinsip Dasar Ilmu Gizi. Jakarta: Gramedia Pustaka Utama.

Andayani, K., 2013. Hubungan Konsumsi Cairan dengan Status Hidrasi Pada Pekerja Industri Laki-lak. Universitas Diponegoro.

Armstrong, L.E., Maresh, C.M., Castellani, J.W., Bergeron, M.F., Kenefick, R.W., LaGasse, K.E. dan Riebe, D., 1994. Urinary Indices of Hydration Status. International Journal of Sport Nutrition, [daring] 4(3):265279. Tersedia pada: < doi/10.1123/ijsn.4.3.265>.

Ashadi, A. dan Anisa, A., 2017. Konsep Disain Rumah Sederhana Tipe Kecil dengan Mempertimbangkan Kenyamanan Ruang. NALARs, 16(1):1-14.

Asmadi, 2008. Teknik Prosedural Keperawatan: Konsep dan Aplikasi Kebutuhan Dasar Klien. Jakarta: Salemba Medika.

Effendi, A., 2016. Hubungan Iklim Kerja dengan Tingkat Dehidrasi pada Pekerja Home Industry STMJ Surabaya. Skripsi. Universitas Airlangga.

Grandjean, A.C., 2009. Water requirements, impinging factors and 
recommended intakes. Working Paper.

Hew-Butler, T.D., Eskin, C., Bickham, J., Rusnak, M. dan Vander Meulen, M., 2018. Dehydration is how you define it: comparison of 318 blood and urine athlete spot checks. BMJ Open Sport \& Exercise Medicine, [daring] 4(1):1-7. Tersedia pada: $<$ doi/10.1136/bmjsem-2017000297>.

Huda, A.I., 2016. Hubungan Beban Kerja Fisik dan Jumlah Konsumsi Air Minum dengan Tingkat Dehidrasi (Studi pada Pekerja di Pabrik Tahu UD Sumber Kencana Surabaya). Skripsi. Universitas Airlangga.

ILO, 2016. Good Practices and Challenges $\mathrm{Ni}$ Promoting Decent Work in Contruction and Infrastructure Project. Geneva.

Moeljosoedarmo, S., 2008. Higiene Industri. Jakarta: Balai Penerbit FKUI.

Nawawinetu, E.D., 2010. Modul Kuliah Heat Stress. Surabaya: Universitas Airlangga.

Ningsih, N.K., 2018. Analisis Karakteristik Pekerja, Kondisi Fisik Lingkungan, dan Sanitasi Lingkungan dengan Tingkat Dehidrasi. Skripsi. Airlangga University.

Pranata, A.E., 2013. Manajemen Cairan dan Elektrolit. Yogyakarta: Nuha Medika.

Rasyid, R., 2018. Paparan Iklim Kerja Panas Terhadap Status Hidrasi Pekerja Unit Produksi di PT. Argo Pantes Tbk Tangerang. Jurnal Teknik Mesin ITI, 1(1):18-21.
Rohadi, L.A.A., 2018. Hubungan Beban Kerja Fisik, Lingkungan Kerja dan Jumlah Konsumsi Cairan dengan Status Hidrasi di Divisi Extract Meat Powder (EMP) PT. Ajinomoto Indonesia Mojokerto Factory. Skipsi. Universitas Airlangga.

Sari, M.P., 2017. Iklim Kerja Panas dan Konsumsi Air Minum Saat Kerja Terhadap Dehidrasi. HIGEIA (Journal of Public Health Research and Development), 1(2):108-118.

Sari, N., 2014. Pengaruh Iklim Kerja Panas terhadap Dehidrasi \& Kelelahan Tenaga Kerja bagian Boiler di PT.Albasia Sejahtera Mandiri. Skipsi. Universitas Muhammadiyah Surakarta.

Sayuti, M. dan Susanto, B., 2017. Pengaruh lingkungan kerja terhadap kualitas produk ikm kerupuk udang di kabupaten indramayu. Industry Xplore, 02(01):35-46.

Septiana, N.R. dan Widowati, E., 2017. Gangguan Pendengaran Akibat Bising. HIGEIA (Journal of Public Health Research and Development), 1(1):73-82..

Sukowiyono, G. dan Susanti, D.B., 2018. Fungsi Pawon sebagai Desain Perolehan Panas pada Hunian di Daerah Dingin. Jurnal PAWON, 2(1):69-80.

Suma'mur, 2009. Higiene Perusahaan dan Kesehatan Kerja (HIPERKES). Jakarta : Sagung Seto.

Tarwaka, 2011. Ergonomi Industri, Dasardasar Pengetahuan dan Aplikasi di Tempat Kerja. Surakarta: Harapan Press. 